\title{
Role of Financial Development in Economic Growth: Evidence from Savings and Credits Cooperative Societies in Tanzania
}

\author{
Xuezhi Qin $^{1} \&$ Benson Otieno Ndiege ${ }^{1}$ \\ ${ }^{1}$ School of Business Management, Dalian University of Technology, Dalian, China \\ Correspondence: Benson Otieno Ndiege, School of International Cultural Exchanges, Dalian University of \\ Technology, Dalian 116024, China. E-mail: ndiegebenson@yahoo.com
}

Received: February 28, 2013

Accepted: March 26, 2013

Online Published: April 8, 2013

doi:10.5430/ijfr.v4n2p115

URL: http://dx.doi.org/10.5430/ijfr.v4n2p115

\begin{abstract}
In this paper we examine the role of Savings and Credits Cooperative Societies (SACCoS) in the economic growth of Tanzania by answering two main questions. First, are financial services in SACCoS significant factors for economic growth? Second, are financial services in SACCoS Granger causing economic growth? We use credits-real GDP per capita ratio and savings-real GDP per capita ratio as proxy measures for financial services and real GDP per capita for economic growth. We employ Newey-West standard errors regression model and Wald Granger causality tests in analysis. The sample period is 1990-2012. Data are from the Ministry of Agriculture, Food and Cooperatives, World Economic Outlook (WEO) database, International Monetary Fund (IMF). The findings show that, there is a strong positive association between the financial services and the economic growth, also there istwo-ways Granger causality between them. However, we find out that savings are much important in fostering economic growth as compared to credits/loans. These criteria make SACCoS the distinct microfinance institutions in the economic development in Tanzania and therefore should be promoted with more emphasis on the savings objective.
\end{abstract}

Keywords: Tanzania, SACCoS, microfinance, financial development, economic growth

\section{Introduction}

In the early 1980's, Tanzania adopted Structural Adjustment Programme (SAP) and Economic Recovery Programmes (ERPs) to promote private sector development so as to bring structural change in its economy which was then poorly performing under the state centered economy (Bee, 2007; Akinboade, 2000). The main changes made were in the financial sector where the greatest interest was liberalization of interest rates and the encouragement for the entry of private banks, with the ambition of achieving financial development. This idea of financial reform followed the most supported theory that, financial development is the engine of economic development through influencing investment and business, and improving resources allocation (Hassan, Sanchez, \& Yu, 2011; Wolde-Rufael, 2009; Bee, 2007; Kessy and Urio 2006; Odhiambo, 2005; Darrat, 1999).

Soon after the financial reform positive results were observed in the financial sector, basically, in the form of increased financial intermediations (financial services) in the country (Bee, 2007; Kessy \& Urio, 2006; Akinboade, 2000). According to Akinboade (2000), in thee arly 1990's, the number of commercial banks grew from 3 to 14 before the reform. This raising trend continued and after about twenty (20) years down the line, the nation can witness fantastic development of the financial sector due to massive increase in the number of commercial banks and other formal institutions, and microfinance institutions. For example, according to Central Bank of Tanzania (BOT) reports, in 2012 there were total of 45 formal financial institutions which are 32 national commercial banks, 8 regional commercial banks and other 5 licensed financial institutions.

At the beginning of the reform, only formal financial institutions were the main targets until it was observed that majority of Tanzanian who were in the rural areas were not involved as well as not benefitted from the development of commercial banking system. According to Bee (2007) and Kessy and Urio (2006), the reasons behind this are; first most of the formal financial institutions like commercial banks were located in urban areas due to availability of infrastructure necessary for their security. Second the demand for worth collaterals from clients to minimize their financial risk, which majority of the Tanzanians were not able to afford due to the poverty level and informal ownership of the assets such as land. Due to these shortcomings, it was then observed that microfinance institutions were the functional model which can help to expand financial intermediation (used interchangeably with financial 
services, financial deepening and financial development) in the rural areas. Microfinance financial institutions are those which give financial services such as microcredit to the poor and low income earners citizens.

Generally microfinance institutions and formal institutions have done a good job in the financial intermediations in the country by increasing financial accessibility to majority of the citizens. Satta (1999) reported that, there is evidence that the financial reform brought positive impact on the size of financial system in Tanzania. Also recent studies in microfinance reported that, the two sub-sectors (formal financial institutions such as commercial banks and microfinance) are linking and expanding financial services in both low and middle class populations in urban and rural areas (Ganka, 2010; Temu \& Ishengoma, 2010; Piprek, 2007; Randhawa and Gallardo; 2003). This new experience is viewed as an important tool for financial deepening and for reallocation of resources in the country.

In the microfinance industry in Tanzania, Savings and Credits Cooperative Societies (SACCoS) have gained popularity as the most useful financial tools to majority of the poor people (Temu \& Ishengoma, 2010; Bee, 2007; Randhawa and Gallardo, 2003). This is proved by their distribution and number of clients they have all over the country. Tanzania SACCoS statistical reports show that, up to March 2012, there were 5,424 total numbers of SACCoS, among them were 3,039 in the rural areas, with a total number of 1,059,213 as members all over the country. SACCOS are also known as cooperative-based microfinance institutions because people willingly unite to form financial institutions which allow them to save their money and access credits easily and at lower cost. Therefore members of SACCoS are the owners and controller of the institution(s) (Mataba, 2010; Temu \& Ishengoma, 2010).

Unlike most microfinance institutions including Non-Government (NGOs), the main business of SACCoS is mobilizing and accepting deposits which are important in building internal capacities for individual people, institutions and national as a whole in the form of domestic households' savings. As explained by Ganka (2010) and Okumu (2007), the credits they (SACCoS) provide are mainly from savings with the remaining part financed through borrowing from formal financial institutions especially commercial banks. Through this way, they have made credible impact on financial intermediation in the country for about three decades now. The data published by the Ministry of Agriculture, food and Cooperatives, clearly demonstrate positive trend, whereby both savings and credits provided are increased with time (see Figure 1) which is interpreted as financial deepening. Consequently, if the idea that financial deepening is the mean to attain economic prosperity is factual, then we expect positive response of economic development to the financial development achieved through SACCoS development.
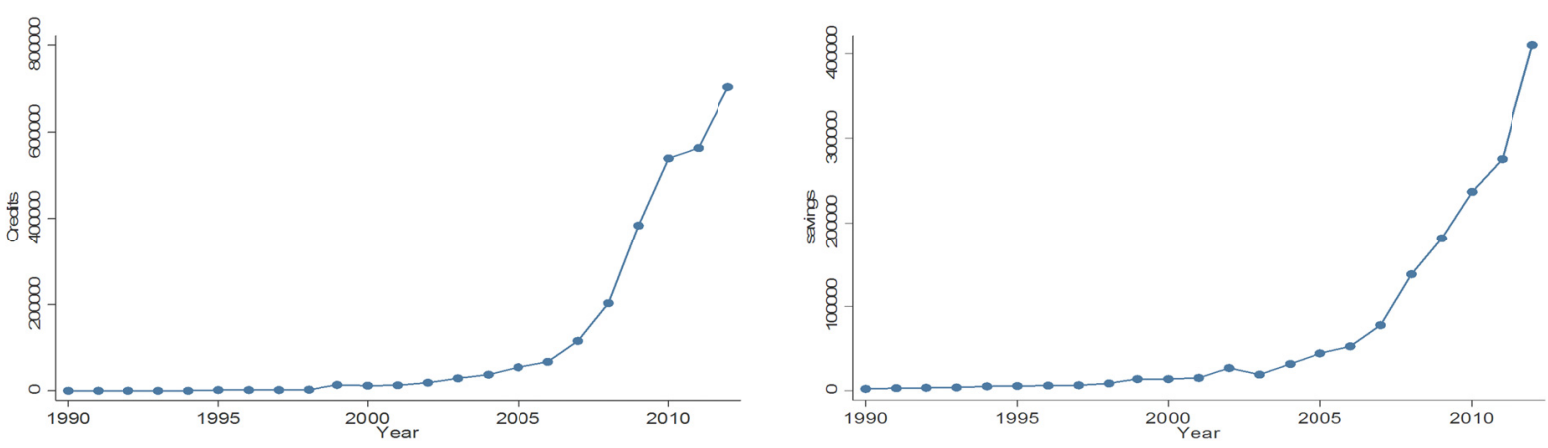

Figure 1. Trend of credits and savings in SACCoS

The graphs show the trend of credits/loan portfolio and total savings (share + deposits +savings) in SACCoS for the period of 1990-2012. We make calculations using Tanzania SACCoS statistical reports which are published by Ministry of Agriculture, Food and Cooperatives in Tanzania. Savings and credits are in million Tanzania shillings. Both savings and credit show rapid growth since 2005.

This study is set to examine whether financial development in cooperatives-based microfinance has a role to play in Tanzanian economic growth. We analyze our objective by answering two questions. The first question is, are financial services in SACCoS significant factors for economic growth? Here we hypothesize that the financial development has positive relations with economic growth. In answering this question we run time series regression model and test hypothesis. This is important to refute or not our hypothesis which is vital for future forecast of economic growth. It is however identified that, to make a strong conclusion on the role of SACCoS in economic development, the use of regression alone is not adequate as it does not explain the causal effects and direction of influence unless Granger causality tests is applied (Gujarati, 2004). Therefore, this brings us to the need for the 
second question. The Second question is, are financial services in SACCoS Granger causes economic growth? This allow us to test for causal effects between financial development and economic growth using Granger causality tests, whereby our assumption is that financial development is Granger causes economic growth.

We are motivated with three factors in this study; first, it is about three decades since the beginning of reforms in financial sector which also involves microfinance, particularly SACCoS (URT, 2005; URT, 2002; URT, 2000). In this circumstance, there is a need to provide critical assessment on how efforts put in developing financial sector contribute to financial deepening and economic development, which is important in policy implications. Second, as per the level of its development Tanzania considers cooperatives, specifically cooperative microfinance institutions as important remedy for poverty (Ganka, 2010; Temu \& Ishengoma, 2010; Bee, 2007; Randhawa\& Gallardo, 2003; URT, 2002; URT, 2000). Therefore this study is eager to present the role of these institutions which carry the flags of both cooperatives and microfinance institutions, in economic growth.

Third is the theoretical debate on the causal and directional relationship between financial deepening and economic growth in which previous researches have no consensus. According to Darrat (1999), the reason behind the debate is that, there have been different proxy measures of financial development in different researches in different circumstances. We therefore think that, it is a piece of contribution to document evidence to this debate by studying a specific sector which is involved in financial development. Hassan et al (2011), Wolde-Rufael, (2009), Odhiambo (2005) and Darrat (1999), explained that generally the reports in related studies falls in four categories, the first group argue that financial development causes economic growth, the situation which is termed as "supply-lending". Following this supposition, most developing countries (including Tanzania) have struggled to develop their financial systems with ambitions of acquiring economic development.

The second group reports the opposite relationship. They argued that, financial development is merely the results of economic development which stimulate the demand for financial services. The factors which are considered to stimulate economic development are human capital development and technology advancement; commonly this situation is known as "demand-following". The third group is those who agree that financial development has effects on economic growth but the inverse is also true. Such analysis shows that there is two-ways traffic between the two components. The last group is those who do not accept any relationship between financial development and economic growth. In this case it means neither of them causes another. It is therefore our work to contribute evidence on this debate using simple set of financial data from SACCoS in Tanzania.

Principally, many studies in this area used cross-country data to make conclusion on the relationship between financial development and economic growth. In some cases researchers use this technique in country level by compiling countrywide data. As mentioned previously in this paper, it is widely accepted that there is no single proxy used in financial development but it is useful to use proxy that is believed to affect enterprise development immediately. In this case, then, the private credit has to be considered the most useful in analysis (Hassan et al, 2011; Wolde-Rufael, 2009; Akinboade, 2000). Therefore we also find it useful to use private domestic credits via SACCoS to identify the contributions of single financial sub-sector and also study its relationship with real per capita income of the country. We however make use of the credits-real GDP per capita ratio and savings-real GDP per capita ratio as proxy measures for financial services and use real GDP per capita for economic growth.

We use loan portfolio to represent credits provided to members of SACCoS in each year to develop one of our financial development proxy which is credit-real GDP per capita ratio. Essentially, there are two sources of funds located in loan portfolio in SACCoS which are members' contributions and commercial loans from commercial banks and other formal non bank financial institutions, government and donors which they lend to members (Ganka, 2010; Okumu, 2007). Also, we use total individuals members contributions in SACCoS to represent savings and develop another financial development proxy measure called savings-real GDP per capita ratio. There are three ways in which members of SACCOS make their contributions. The first is through share. That is, to become a member one need to contribute share. The maximum and minimum size of share differs from one SACCoS to another but generally all SACCoS apply that as way of showing individual readiness to cooperate. The second form of saving is demand deposit. Here members save mainly to accumulate money to finance social services that require big amount of money which an individual cannot raise from income at once. It is also required to finance unexpected phenomenon which may destruct the pattern of individual income. The last component of savings in SACCoS is essentially known as saving (it should not be confused with total savings which we basically referred to in this study). This is the most important form of savings because it determines the ability of individual member to borrow from SACCoS. Generally, savings are important in building internal capacity for individuals, SACCoS as an institution and the nation as a whole. 
In summary, the main focus of this paper is to find out if SACCoS has contribution in economic development despite much praises given in terms of their outreach. Therefore this study makes two contributions; first, because there is belief that SACCoS are important in economic development and an ultimate poverty reduction tool, we develop the evidence on the role of SACCoS in economic development in Tanzania. Second, because there are contradictions on the relationship between financial deepening, this study gives additional knowledge on whether there is a relationship, and if it exists, how it does look like. The findings are believed to be useful to the government, policy makers, researchers and all other stakeholders in SACCoS and financial sectors as a whole.

\section{Literature Review}

Many scholars have written on the role of SACCoS in economic development especially for the developing countries, whereby their general conclusion is that SACCoS is doing praiseworthy work in savings, investment and poverty reduction. Among these are Lafourcade (2005) who reported that microfinance in Africa including SACCoS are speedily growing in number and members, and their activities are increasing in most African countries. The same conclusion was made by Temu and Ishengoma (2010) and Randhawa and Gallardo (2003) who used Tanzania as case study in their works. They both added that SACCoS are the most popular microfinance institutions in the county especially in rural area.

Ganka (2010) and Bee (2007) also made supportive arguments that, SACCoS have a role in rural financial marketing and outreach in Tanzania where their findings demonstrated that these institutions have become useful in increasing financial services specifically credits accessibility. In Uganda, Tache (2007) studied contributions of SACCoS to the rural peasants and the report showed that SACCoS has been playing creditable role in empowering peasants by giving them opportunity to make savings. Moreover, Wanyama (2008) stipulated that cooperative financial institutions have spectacular importance in employment which is important in improving living standards among low income earners and poor people in Kenya. Indeed most of these works focused on microfinance as a whole and then SACCoS is treated as an element within the study. This does not give reflective description of the contribution of SACCoS as independent and unique microfinance institutions. Also, it is evident that there is no current study found specifically narrating the level and linkage of financial services in SACCoS and economic growth.

However, while most of the studies agreed on the relationship between financial development and economic growth, the theoretical debate on directional and causal effects remain the central debate (Hassan et al, 2011; Wolde-Rufael, 2009; Odhiambo, 2005; Akinboade, 2000; Darrat, 1999). Commonly, policymakers continue to emphasize on the role financial development play on economic growth, and hence most countries especially developing continues put more effort on developing their financial systems (Hassan et al, 2011; Akinboade, 2000). On other hand, scholars continue to find out the consensus on the theory. Therefore, studies in and outside Tanzania always tried to find the link between economic growth and financial development in different dimensions such as coverage, level of development and type of proxy measures.

For example, across countries Darrat (1999) studied the three Middle East countries; Turkey, Saudi Arabia and United Arab Emirates, and concluded that generally financial development contribute to economic growth. Hassan et al (2011) used more comprehensive data which covered low and middle income countries and found that there was two-ways relationship between financial development and economic growth. Also in a study within one country, Wolde-Rufael (2009) re-examined the link between financial development in Kenya and economic development and found bidirectional Granger causality.

In Tanzania, two studies were found and they were studies by Akinboade (2000) and Odhiambo (2005). Akinboade study's examined two periods which were before financial liberation (1966-1981) and after (1982-1996) and made two important conclusions. First, financial development was negatively related to economic growth and significant (in the period of 1966-1981), and the second point was that, the two variables were independent (in the period of 1982-1996). Odhiambo found two evidences. One was supply-lending when he use ratio of broad money to GDP and bidirectional when he used ratio of private sector credits to GDP. All the literatures which were selected and used in this paper portray that the use of different proxies for financial deepening produces different results and conclusions.

However, no study linked directly the role of SACCoS in economic growth especially in Tanzania. Since SACCoS are promoted to meet financial development of which the government and policymakers believe that will results to economic growth and hence poverty reduction, then there is a need to measure the relationship between the two variables within a country using this individual sub-sector to analyze the performance of an individual sub-sector in economy. This paper presents the linear relationship and Granger causality between financial development and economic growth. 


\section{Data Sources and Definition of Variables}

We use time series data that covers the period of 1990-2012. This period is within the time of the financial liberalization and development in Tanzania. During this period, increase in investment, economic growth and per capita income is supposed to have resulted from the financial reform which has existed almost for three decades. There are two sets of data. The first set of the data is of financial deepening in SACCoS which are gathered from Ministry of Agriculture, Food and Cooperatives in Tanzania. This set of data is about credits and savings which are used to calculate proxy measures for financial deepening. The second set of data is on GDP per capta, real interest and inflation and is collected from World Economic Outlook (WEO) database, International Monetary Fund (IMF) last update in October 2012.

We use real GDP per capita (RPGDP) as proxy measure for economic growth which is a common measure for economic growth. Also, two proxies were used to measure for financial deepening. The first is credits divided by real GDP per capita (CGDP). The assumption here is that, the higher the CGDP, the higher the financial deepening and hence the high the economic growth. As shown before in section 1 of this paper, credits are total loans provided to the members and then they represent domestic credits to private. Various authors including Hassan et al (2011), Wolde-Rufael (2009), and Akinboade (2000) have explained the variability, complexity and shortcomings of the various financial deepening proxies' measures. They have concluded that among all proxies, the growth of domestic credit to private sector indicates that there are both growths in financial development as well as domestic investment, which are useful in economic growth.

The second proxy of financial deepening we use is savings divided by real GDP per capita (SGDP). As mentioned in the early part of this paper, savings is the summation of all contributions of the members to the SACCoS which are in three forms share, deposits and savings. Savings are important financial services provided by SACCoS and they are the main part of loan portfolio (Ganka, 2010; Temu \& Ishengoma, 2010; Okumu, 2007), which is described in this paper as domestic credits to the private sector. In this manner, savings are useful in the analysis of economic growth. Previous researches showed that savings promote investment and hence affect economic development positively based on the portion directed to the investment (Onchangwa \& Memba, 2012; Hassan et al 2011; Kabete, 2008; Deaton, 2005). The logic behind these literatures is that, the capabilities to save determine how a country can invest and efficiently utilize its recourses because savings enable capital formation and resources reallocations.

We mainly use these two ratios because from the common meaning, financial deepening is the increase in financial services which basically involves deposits and credits. For example, in developing the model to study relation between interest and economic growth, Obamuyi (2009), identified that both private sector credits and domestic savings capture the effects of financial deepening. Therefore we have no doubt that these measures will document the effect of financial deepening in SACCoS sub-sector because; first they show the ability of institutions to direct funds from surplus to deficit areas and hence implies proper reallocations of resources in the economy. Second, SACCoS are results of financial reforms and this information is accurate to reveal the relationship between national finance development and economic growth.

In addition to the proxy measures described above, we used inflation rate (INFL) and real interest rate (INTR) in our model mainly as controlling variables. INFL is an important variable because various researchers demonstrate that it has effects on economic growth. According to Darrat (1999), inflation distorts prices, generally has negative effects on economy. Also other researchers like Odhiambo (2011) explained that there is a causal relationship between inflation and economic growth. Moreover, Obamuyi (2009) illustrated that higher rate of inflation lower the rate of economic growth. Following these observations, it is useful to include INFL in our model to improve the strength of our tests, and the hypothesis in that, the higher the INFL the lowers the economic growth. Also, Obamuyi (2009) indicated that, lower INTR motivates investment, productivity and hence economic growth. In this paper we also hypothesize that INTR have negative relationship to economic growth.

\section{Methods of Analysis}

We have used two methods in our analysis which are time series regression model and Granger test. Using these two analytical tools help us to capture both the correlation between financial development and economic growth, and to identify the fundamental causal and directional relationship between them. It is important to use these two analytical tools because they are very useful to understand whether there is a correlation between the two variables for policy implication, but it is also vital to understand whether these two variables have casual relationship, because the main reason for financial reform in Tanzania has been to foster economic development and reduce poverty. 


\subsection{Time Series Linear Regression Model}

Liner regression model is an econometric model which depicts that dependent variable is linearly related to the independent variable whereby the relationship between the two is not exact but subject to individual variations (Gujarati, 2004). Once the coefficients for explanatory variables (financial deepening) are estimated, the model is used to determine and explain the variable (economic growth) for policy implications. Then the econometric model for time series is identified as:

$$
(\text { RPGDP })_{\mathrm{t}}=\beta_{0}+\beta_{1}(\mathrm{CGDP})_{\mathrm{t}}+\beta_{2}(\mathrm{SGDP})_{\mathrm{t}}+\beta_{3}(\mathrm{INFL})_{\mathrm{t}}+\beta_{4}(\mathrm{INTR})_{\mathrm{t}}+\mu_{\mathrm{it}}
$$

Where $\beta$ 's are the coefficients for the constant and the independent variables, $t$ is time in years and $\mu_{\mathrm{it}}$ are the residuals. The model is a multiple linear regression model because we have more than one independent variables and it is basically linear in both parameters and variables. Therefore in this model we apply ordinary least square (OLS) in determining the coefficients of proxy variables for financial deepening. We choose OLS because it is simple to use (Guajarati, 2004).

Then the null hypothesis $\left(\mathrm{H}_{0}\right)$ is; $\mathrm{H}_{0}=\beta_{1}=\beta_{2}=\beta_{3}=\beta_{4}=0$, and F-statistic is used in rejecting or not rejecting the model and $p$-values are used to reject or not reject coefficient of independent variable.

Before the estimation of the parameters, we run Pairwise correlations to get correlation coefficients for all five independent variables as it is shown in Table 1. This step does not only help us to identify the correlation between our variables but also help us in modifying our basic model in Equation 1.

Table 1. Summary results of pairwise correlation coefficients

\begin{tabular}{llllll}
\hline & RPGD & CGDP & SGDP & INFL & INTR \\
\hline RPGD & 1.0000 & & & & \\
CGDP & 0.9266 & 1.0000 & & & \\
SGDP & 0.9390 & 0.9861 & 1.0000 & & \\
INFL & -0.3847 & -0.1989 & -0.2218 & 1.0000 & \\
INTR & -0.2524 & -0.2509 & -0.2654 & -0.0156 & 1.0000 \\
\hline
\end{tabular}

The results in Table 1 show that the correlation coefficient between; RPGDP and CGDP is +0.92 , RPGDP and SGDP is +0.93 , RPGDP and INFL is -0.38 , RPGDP and INTR is -0.25 , and CGDP and SGDP is +0.98 .

The results demonstrate that CPGDP and SGDP are highly correlated which might be an indication of the presence of multicollinearity problem in the proposed model. According to Gujarati (2004) high correlation among independent variables is an indication of multicollinearity. We therefore run a regression and find multicollinearity problem in the model which is distorting the directions of coefficients. In that case, as recommended by Gujarati (2004), one of the two variables can be dropped as a remedy for multicollinearity. However, because we want to demonstrate the role of each financial deepening proxy measure in economic development, we decide to run two linear regression models as presented in equation 2 and 3, where we drop SGDP in the first model and drop CGDP in the second model.

$$
\begin{aligned}
& (\text { RPGDP })_{t}=\beta_{0}+\beta_{1}(\text { CGDP })_{t}+\beta_{2}(\text { INFL })_{t}+\beta_{3}(\text { INTR })_{t}+\mu_{i t} \\
& (\text { RPGDP })_{t}=\beta_{0}+\beta_{1}(\text { SGDP })_{t}+\beta_{2}(\text { INFL })_{t}+\beta_{3}(\text { INTR })_{t}+\mu_{i}
\end{aligned}
$$

For the two econometric models specified above $(2 \& 3)$ we estimate linear regression models using Ordinary Least Square (OLS) regressions at $95 \%$ confidence interval, and the results are that our models are best by having $\mathrm{R}^{2}$ of $90 \%$ for each and signs in coefficients are as hypothesized in each variable. For both models we test for heteroskedasticity, autocorrelation and multicollinearity problems. We use Breusch-Pagan/Cook-Weisberg to test for heteroskedasticity to see if there is constant variance. The null hypothesis is that there is constant variance. Also we use Durbin's alternative to test for autocorrelation with null hypothesis that there is no serial correlation and lastly we apply variance inflation factors (VIF) for the independent variables for multicollinearity respectively as in Table 2 . 
Table 2. Heteroskedasticity, autocorrelation and multicollinearity tests after OLS regression

\begin{tabular}{llll}
\hline \multicolumn{3}{c}{ Breusch-Pagan / Cook-Weisberg test for heteroskedasticity } \\
\hline \multicolumn{4}{c}{ Ho: Constant variance } \\
& Variables: fitted values of RPGDP \\
model & Chi-square (1) & Probability value of Chi-square & Decision \\
1 (SGDP dropped) & 0.02 & 0.8816 & Not Reject Ho \\
2(CGDP dropped) & 1.31 & 0.2528 & Not Reject Ho \\
\hline
\end{tabular}

\begin{tabular}{llllll}
\hline \multicolumn{6}{c}{ Durbin's alternative test for autocorrelation } \\
\hline & $\operatorname{Lag}(p)$ & Chi-square & df & Probability value of chi-square & decision \\
1 (SGDP dropped) & 1 & 23.481 & 1 & 0.0000 & Reject Ho \\
2(CGDP dropped) & 1 & 27.536 & 1 & 0.0000 & Reject Ho \\
\hline
\end{tabular}

\begin{tabular}{llcccc}
\hline \multicolumn{5}{c}{ Variance Inflation Factors $($ VIF) for the independent variables } \\
\hline Variable & Model 1 & 1/VIF & Variable & VIF & Model 2 VIF \\
CGDP & 1.12 & 0.895897 & SGDP & 1.14 & 0.878499 \\
INFL & 1.07 & 0.932563 & INFL & 1.08 & 0.923733 \\
INTR & 1.05 & 0.955863 & INTR & 1.06 & 0.944827 \\
mean & 1.08 & mean & 1.09 & No multicollinearity \\
Decision & No multicollinearity & Decision & & No
\end{tabular}

From Table 2, for the reason that probability value of chi-square is above 5\% significant level in Breusch-Pagan / Cook-Weisberg test for heteroskedasticity, we do not reject null hypothesis that there is homoskedasticity in both tests. Also using probability value of chi-square which is below $5 \%$ significant level in Durbin's alternative test for autocorrelation, we reject null hypothesis that there is no serial correlation in both tests. In addition the models are safe from multicollinearity at 0.05 significant levels because mean VIFs are less than 5.

Therefore both models are free from heteroskedasticity and multicollinearity but suffering from autocorrelation problem. According to Gujarati (2004), when time series are fitted in OLS, if the disturbances are autocorrelated, the parameters are always consistent but standard errors are underestimated. Thus, as a solution for this problem, we use Newey-West standard errors regression model in univariate time series in estimations. Newey model gives the same parameters estimates as OLS but in addition it is used in residual autocorrelation and heteroskedasticity in the error terms corrections (Gujarati, 2004; Newey and West, 1987).

\subsection{Granger Causality Test}

We use multivariate time series model in the analysis of the relationship between financial deepening and economic development. The model is useful in determining the association of financial deepening and economic growth by examining causality and direction of their proxy measures using Granger causality tests. Granger causality test has become the popular in different researches which determine the direction of the causality between two or more variables especially when financial time series are involved in the analysis. Darrat (1999) pointed out that, the main reasons are that the method is simple and it offers some degree of freedom in small samples. Also this method is much useful in financial economics because many variables in this area are non-normally distributed. In common interpretation, Variable A is said to be Granger causes B if B can be better predicted by the histories of both A and B than if it can be predicted using B itself or we can say Variable A is said to Granger cause variable B, if the lags of A can get better a forecast for variable B. According to Sims (1972), the Granger causality tests suppose that variables are endogenous, and therefore when $\mathrm{A}$ is exogenous of B it fails to Granger causes B.

Basically Granger causality is designed to test causal relationship between two variables and it may lead to misleading results when there are more than two variables, but this is handled when vector autoregession (VAR) is used prior to Granger causality tests. We therefore tested for Granger causality following VAR which is designed to capture linear independencies among multiple time series variables where each variable has its equation based on its own lags and lags of the other variables in the models (Guajarati 2004). Therefore, we test for financial development proxy variables (CGDP, SGDP) and INFL and INTR to find out which Granger causes economic growths are and which ones are not. 
We have followed Toda and Yamamoto (1995) approach in the test for Granger causality. This approach, unlike other approaches which are based on Error-Correction Model (ECM) that requires unit test so as to develop stationary time series, it uses standard autoregession with non-stationary without differentiations, and uses Granger causality Wald tests statistic which uses probability value of chi-square (see Hassan et al, 2011 and Wolde-Rufael, 2009). Therefore, in VAR modeling we include all five proxy measures which are RPGDP, CGDP, SGDP and INFL and INTR, so that our model is five by five matrix. In this model, mainly the null hypothesis is that, the variable financial development (CGDP and SGDP) does not Granger causes the variable economic growth (RPGDP), therefore the summation of the coefficients on the lags of variables CGDP and SGDP will be zero in the equation for variable RPGDP. This test is also done inverse for CGDP not Granger causes CGDP and SGDP. We adopt Hassan $e t$ al (2011) VAR model to develop a model for this test as:

$$
\mathrm{B}_{\mathrm{t}=\mathrm{C}}+\sum_{s=1}^{m} A_{\mathrm{s}} \mathrm{B}_{\mathrm{t}-\mathrm{s}}+\mu_{\mathrm{t}}
$$

Where $B_{t}$ is the $5 \times 1$ vector of column for proxy measures, $C$ and $A_{s}$ are the coefficients of $5 \times 1$ and $5 \times 5$ matrices coefficients, $\mathrm{m}$ is length of lags and $\mu_{\mathrm{t}}$ is a $5 \times 1$ column vector of errors.

We test for lag length by applying selection criteria as presented in Table 3. We use Akaike's information criterion (AIC) and final prediction error (FPE) to determine the optimal lag length; because they are superior to other criteria when less than 60 observations are under study (Liew, 2004). AIC chosen $4^{\text {th }}$ lag and FPE $3^{\text {rd }}$ lag. However, the results show that, all lag proxy measures are significant at $1 \%$ significant level. In this case, we are forced to test $3^{\text {rd }}$ and $4^{\text {th }}$ lags in Wald Granger causality tests, and upon testing we find out that, Wald tests are not producing any results with $4^{\text {th }}$ lag. So we opt to use $3^{\text {rd }}$ lag as it is recommended by FPE and lastly run Wald Granger causality tests whereby p-value was use for rejecting null hypothesis.

Table 3. Lag length selection determined after VAR

\begin{tabular}{|c|c|c|c|c|c|c|c|c|}
\hline \multicolumn{9}{|c|}{ varsoc RPGDP CGDP SGDP INFL INTER, maxlag(4) } \\
\hline \multicolumn{9}{|c|}{ Selection-order criteria } \\
\hline \multirow{2}{*}{\multicolumn{5}{|c|}{$\begin{array}{l}\text { Sample: } \\
\text { Number of obs }\end{array}$}} & \multicolumn{2}{|l|}{1994} & - & \multirow[t]{2}{*}{2012} \\
\hline & & & & & & & & \\
\hline lag & LL & LR & df & $\mathrm{p}$ & FPE & AIC & HQIC & SBIC \\
\hline 0 & -842.35 & & & & $3.8 \mathrm{e}+32$ & 89.1947 & 89.2368 & 89.4433 \\
\hline 1 & -738.081 & 208.54 & 25 & 0.000 & $1.0 \mathrm{e}+29$ & 80.8506 & 81.103 & 82.3418 \\
\hline 2 & -675.874 & 124.41 & 25 & 0.000 & $4.0 \mathrm{e}+27$ & 76.9341 & 77.3968 & 79.668 \\
\hline 3 & 48.9643 & 1449.7 & 25 & 0.000 & $.000859 *$ & 3.26691 & 3.93991 & 7.2435 \\
\hline 4 & 2017.98 & $3938 *$ & 25 & 0.000 & . & $-202.419 *$ & $-201.62 *$ & $-197.69 *$ \\
\hline
\end{tabular}

* show selected lag length in each selection criterion

\section{Empirical Results and Discussion}

This paper has two specific objectives; the first one is to determine whether financial development through SACCoS has a relationship with the economic growth. In this case, we use correlation coefficients and time series linear regression to determine the relationship between financial development and economic growth. The dependent variable are real GDP per capita (RPGDP) while independent variables are credits/loan (CGDP), savings (SGDP), inflation rate (INFL) and real interest rate (INTR). Then, Newey-West standard errors regression was used in the estimation. Table 4 below presents the summary results.

Table 4. The summary of Newey-West standard errors regressions results

\begin{tabular}{llllll}
\hline \multicolumn{5}{c}{ Dependent variable is RPGDP } \\
\hline \multicolumn{5}{l}{ Model 1 (SGDP dropped) } \\
Probability of F-statistics $=0.0000$ & \multicolumn{5}{c}{ Model 2 (CGDP dropped) } \\
$\begin{array}{l}\text { Variable } \\
\text { constant }\end{array}$ & Coefficient & t-value & Probability of F-statistics $=0.0000$ \\
CGDP & 277436.7 & $(16.18)^{*}$ & Cariable & Coefficient & t-value \\
INFL & .1124055 & $(14.87)^{*}$ & SGDP & 265527.8 & $(16.96)^{*}$ \\
INTR & -1350.001 & $(-3.38)^{* *}$ & INFL & -2288617 & $(9.46)^{*}$ \\
\hline
\end{tabular}

The t-statistics are in brackets. ${ }^{* *}, * * *$ represent that the coefficient is significant at $1 \%, 5 \%$ and $10 \%$ significant level respectively. 
From Table 4, the results demonstrate that both proxy measures for financial development (CGDP and SGDP) have positive relationship with economic growth and significant at $1 \%$. This indicates that, increase in credits and savings is significant to the economic growth. In terms of coefficients which give information on magnitude of relationship, the results indicate that, the relationship between SGDP and RPGDP is stronger, almost twice to that of CGDP and RPGDP. The implication is that, increase in savings is more crucial in economic growth than credits. Using SACCoS savings to represent domestic saving, we observe that domestic savings has extraordinary role in per capita income in Tanzania. The results also support Obamuyi (2009) that, inflation has negative effects on economic development. Unfortunately, the interest rate was found to be an insignificant factor in economic growth though it has negative relation to economic growth as also reported by Obamuyi.

The second objective is to establish whether financial development is Granger causes economic growth. We have used vector autoregession (VAR) and test for Wald Granger causality in this situation. Table 5 shows the summary results for Granger causality Wald tests

Table 5. Summary results for Granger causality Wald tests

\begin{tabular}{|c|c|c|c|c|}
\hline \multicolumn{5}{|c|}{$\mathrm{H}_{0}$ : variable in "excluded" column does not Granger causes the corresponding variable in "equation" column. } \\
\hline Equation & Excluded & chi2 & $\mathrm{df}$ & Probability ofchi-square \\
\hline RPGDP & CGDP & 7.0591 & 3 & $0.070 * * *$ \\
\hline RPGDP & SGDP & 12.105 & 3 & $0.007 *$ \\
\hline RPGDP & INTR & 20.3 & 3 & $0.000^{*}$ \\
\hline RPGDP & INFL & 44.788 & 3 & $0.000 *$ \\
\hline RPGDP & ALL & 71.208 & 12 & $0.000 *$ \\
\hline CGDP & RPGDP & 35.402 & 3 & $0.000^{*}$ \\
\hline CGDP & SGDP & 162.15 & 3 & $0.000 *$ \\
\hline CGDP & INTR & 9.3237 & 3 & $0.025 * *$ \\
\hline CGDP & INFL & 20.435 & 3 & $0.000^{*}$ \\
\hline CGDP & ALL & 251.11 & 12 & $0.000 *$ \\
\hline SGDP & RPGDP & 36.035 & 3 & $0.000 *$ \\
\hline SGDP & CGDP & 227.04 & 3 & $0.000 *$ \\
\hline SGDP & INTR & 15.533 & 3 & $0.001 *$ \\
\hline SGDP & INFL & 17.276 & 3 & $0.001 *$ \\
\hline SGDP & ALL & 339.72 & 12 & $0.000 *$ \\
\hline INTR & RPGDP & 37.347 & 3 & $0.000 *$ \\
\hline INTR & CGDP & 1.161 & 3 & 0.762 \\
\hline INTR & SGDP & 10.309 & 3 & $0.016^{* *}$ \\
\hline INTR & INFL & 49.571 & 3 & $0.000 *$ \\
\hline INTR & ALL & 99.305 & 12 & $0.000 *$ \\
\hline INFL & RPGDP & 67.394 & 3 & $0.000 *$ \\
\hline INFL & CGDP & 8.7947 & 3 & $0.032 * *$ \\
\hline INFL & SGDP & 9.116 & 3 & $0.028 * *$ \\
\hline INFL & INTR & 10.699 & 3 & $0.013 * *$ \\
\hline INFL & ALL & 90.123 & 12 & $0.000 *$ \\
\hline
\end{tabular}

$*$, **, *** indicate significant level at $1 \%, 5 \%$ and $10 \%$ respectively and used for rejecting or not null hypothesis. Variable are RPGDP = economic real GDP per capita, CGDP = credits divide by RPGDP, SGDP = savings divide by RPGDP, INFL = inflation rate and INTR = real interest rate. Data set period 1990-2012. Lag selection criterion was final prediction error (FPE) and optimal lag length is 3.

The results demostrate that generally all variable used in this model are related and has causal effect to each other. Starting with CGDP, it is significant at $10 \%$ and therefore we reject null hypothesis that it does not Granger causes RPGDP. Also in SGDP the p-value indicates that, it is highly significant and therefore Granger causes RPGDP. The lower p-value in case of SGDP than in CGDP, is an indication that savings have higher effect on economic growth than loans/credits provided to individuals. Therefore building institutions with higher capacity to mobilize savings is much more important than concentrating on institutions which their aim is to provide loans and probably make as much profit as possible. In this cirumstances, savings and cooperative societies are much usefull in economic development in Tanzania because their foremost objective is to mobilize savings. Also the results indicates that, the p-values for RPGDP is small enough to reject null hypothesis that RPGDP is not Granger causes CGDP and SGDP 
which proxy measures for financial deepening. For this circumstance then, there is bidirectional Granger causality between economic growth and financial development. Futhermore, we reject null hypothesis that inflation rate (INFL) and interest rate (INTR) are not Granger causes economic growth RPGDP and vise versa.

\section{Conclusion}

We examine the linear relationship between financial development and economic growth using newey-west standards errors regression model, using Savings and credits CooperativeSocieties as our case study. The findings are that, there is a strong association between the two economic variables. More specifically, we find out that, savings are much more important in fostering economic development as compared to credits. Also, we determined Granger causality between the financial development and economic growth using vector autocregression model. The wald Granger causality results portray that, there is two-way Granger causality between savings and economic growth and credits and economic growth. These results are consistent with the finding of Hassan et al (2011) and Wolde-Rufael (2009) who found evidence of bidirectional Granger causality between financial development and economic growth. This means that, the results in this paper support the idea that, financial develoment and economic growth are all boosting each other. Finally, we observe and therefore support the observations by Temu and Ishengoma (2010) and Randhawa and Gallardo (2003) who argued that, SACCoS are the distinct microfinance institutions in the economic development and poverty reduction in Tanzania. We therefore strongly recommend that, these institutions should be promoted by emphasizing on the savings objectives.

\section{Acknowledgment}

The research is supported by the Ph. D. Programs Foundation of Ministry of Education of China (20090041110009), National Science Foundation of Ministry of China (71171032), and the central university special funds for basic research business expenses (DUT11RW202, DUT10ZD107).

\section{References}

Akinboade, O.A. (2000). The relationship between financial deepening and economic growth in Tanzania. Journal of international development, 12 , http://dx.doi.org/10.1002/1099-1328(200010)12:7<939::AID-JID668>3.0.CO;2-I

Bee, F. K. (2007). Rural financial market in Tanzania: An analysis of Access to financial services in Babati District, Manyara Region. $\mathrm{PhD}$ thesis subnited at the University of South Africa.

Darrat A.F. (1999). Are Financial Deepening and Economic Growth Causally Related? Another Look at the Evidence. International Economic Journal, 13(3), 19-35. http://dx.doi.org/10.1080/10168739900000002

Ganka, D.N. (2010). Financial sustainability of rural microfinance institutions (MFIs) in Tanzania. PhD thesis submitted at the University of Greenwhich.

Gujarati, D.N. (2004). Basic econometrics ( $4^{\text {th }}$ ed.). The McGraw-Hill Companies.

Hassan, M. K., Sanchez, B., \& Yu, J. (2011). Financial development and economic growth: New evidence from panel data. The Quarterly Review of Economics and Finance, 5, 88-104.

Kabete, C.N. (2008). Foreign aids and Economic growth; the case of Tanzania. Institutes of Social Studies(ISS), Nethelands. Retreived $12^{\text {th }}$ October 2012, from google.co.uk

Kessy,S.S.A., \& Urio, F. M. (2006). The contribution of Microfinance institutions to Poverty Reduction in Tanzania. Research Report No. 06.3.

Lee, J. (2005, March $4^{\text {th }}$ ). Financial intrmediation and economic growth; evidence from Canada. Paper presented at the Eastern Economics Association, New York.

Liew, V.K. (2004). Which lag length selection creteria should we employ? Economics bulletin, 3(33), 1-9.

Mataba, L. (2010). Sustainable Loan Interest Rates Setting in Saving and Credit Cooperative Societies: A Strategy Towards Building Viable Microfinance Institutins (MFIs). Muccobs Research Report Series, 3.

Newey, W. K., \& West, K. D. (1987). A Simple, Positive Semi-definite, Heteroskedasticity and Autocorrelation Consistent Covariance Matrix. Econometrica, 55(3), 703-708. http://dx.doi.org/10.2307/1913610

Obamoyi, T.M. (2009). An investigation of relationship between interest rates and economic growth in Nigeria. Journal of Economics and International Finance, 1(4), 093-098.

Odhiambo, N.M. (2005). Financial development and economic growth in tanzania; a dynamic causality test. The African Finance Journal, 7(1), 1-17. 
Odhiambo, N.M. (2011). Inflation dynamics and economic growth in tanzania; a multivariate time series model. Las vegus international academic conference, las vegas, usa.

Okumu, J.L. (2007). The microfinance in Uganda; sustainability outreach and regulation. PhD Desertation presented at the university of stellenbosch.

Onchangwa, G.A., \& Memba, F.S. (2012). Does a savings and credits cooperative society (SACCOs) have any effect on members' investment culture in Kenya? International journal of Arts and commerce, 1(6), 160-166.

Piprek, G. (2007). Linking with Saving and Credits Cooperative (SACCoS) to expand Financial Access in Rural Areas: A case study of CRDB Bank in Tanzania.

Randhawa, G. $\left(2012\right.$, December $\left.30^{\text {th }}\right)$. Foreighn aids in economic development. E-journal of International Journal of Computing \& Business Research. Retrived from http://www.researchmanuscripts.com/isociety2012/38

Satta, T.A. (1999). Financial Sector Reforms and the Development of Financial Intermediaries in Tanzania: 1985-1997. African Journal of Finance and Management, 7(2), 128-143. http://dx.doi.org/10.4314/ajfm.v7i2.24354

Sims, C. (1972). Money, Income and Causality. American Economic Review, 62, 540-552.

Tache, G.M. (2007). Farmers empowering themselves - saving together. United States Agency for International Development.

Tanzania Federation of Cooperatives. (2006). Simplified Guide to the Cooperative Development Policy and Cooperative Societies Acts of Tanzania Mainland. Dar es Salaam.

Temu, S.S., \& Ishengoma, E.K. (2010). Financial linkages and performance of rural microfinance cooperatives: Tanzanian case. Indian Journal of Economics and Business, 9(2), 285-302.

URT. (2000). Microfinance Policy. Dar es Salaam: Ministry of Finance .

URT. (2002). Cooperative Development Policy. Dar es Salaam: Ministry of Agriculture and Cooperative .

URT. (2005). National Strategy for Growth and Reduction of Poverty. Dar es Salaam

Wolde-Rufael, Y. (2009). Re-examining financial development and economic growth in Kenya. Economic Modeling, 26, 1140-1146. http://dx.doi.org/10.1016/j.econmod.2009.05.002 